\title{
Referendum process in the era of personalization of politics: a descriptive case study of constitutional referendum in 2010, Turkey
}

\author{
Nigar Değirmenci \\ Pamukkale University, Turkey \\ E-mail: ndegirmenciepau.edu.tr
}

\begin{abstract}
A constitutional referendum on some amendments to the 1982 Constitution was held in Turkiye on 12 September 2010. The amendments voted by $78 \%$, about $58 \%$ voted "Yes", and $42 \%$ voted "No."The referendum process had faced a propaganda war throughout the media between political leaders. This

study seeks to answer this question: Is there any evidence for political personalization of politics in the political speeches of the political leaders and media news? According to the study results, we concluded that there has been "a spiral of personalization" process in Turkiye on the ground of media. ${ }^{1}$
\end{abstract}

Keywords: personalization of politics; political discourse; political speeches; referendum; political leaders.

\section{INTRODUCTION}

7 HE hitherto studies have shown that the world politics have been in a transformation process 1 in which political parties and ideas becomes less powerful while the leaders are becoming more powerful (Mair, 2005) in other words, politics have become more personalized. This process has been called as "personalization of politics". Although some studies have no evidence that leaders have become more important to vote and have only a little evidence that party effects have diminished (Gidengil, 2000; Kaase, 1994: Schulz et al, 2005). Since the 1980s, there has been a growing tendency to emphasize the personal role of leaders as figureheads of their party's electoral campaign (Paloheimo, 2005:258, Karvonen, 2007: Castells, 2009). Castells claims that there are 3 main developments cause that transformation in American political life [according to our view this transformation is not restricted to American, also in European politics but only it may be weaker in Europe] in the last years of the century 20th: a) Declining of political parties,

Data de submissão: 2016-12-04. Data de aprovação: 2017-05-04.

A Revista Estudos em Comunicação é financiada por Fundos FEDER através do Programa Operacional Factores de Competitividade - COMPETE e por Fundos Nacionais através da FCT - Fundação para a Ciência e a Tecnologia no âmbito do projeto Comunicação, Filosofia e Humanidades (LabCom.IFP) UID/CCI/00661/2013.

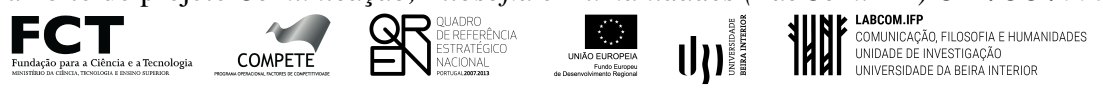

1. An earlier version of this paper is was prepared and presented at $61^{\text {st }}$ UK Political Studies Association Annual Conference Transforming Politics: New Synergies 19 - 21 April 2011. Novotel London West and is no longer published on the conference papers site. 
b) Far complicated and ubiquities media than ever before, and c) political polls, simultaneous political marketing by political polls, online marketing, etc. (Castells, 2009:478). Those three developments are supported by Campus's claim which is suggesting that "when most of the old parties disappeared or had to change their name and outlook to survive, voters lost the reference points with which they used to orient themselves in the complex political world." At that point, leaders appeared as an anchor, a shortcut to making voting decisions without being obliged to fully understand the political developments (Campus, 2010:4). Mancini and Swanson explain that development "(...) the traditional ideological party that was so common in Europe and elsewhere until just a few years ago is being replaced by catch-all parties devoted to personalization." The personalization proceeds more rapidly in majority systems are focused more sharply on the role of television, which stresses the simplification of choice between one party and the other. (Mancini \& Swanson, 1996:18)

When it comes to Constitutional Changes, it is more complicated. A rational referendum on a bunch of constitutional amendments requires knowledge in Law. But it is usually too complicated to vote as just "yes" or "no" to all. At this point, Campus's claim plays an important role. Voters have used the "leader" anchor to have a decision on politics for the last decades increasingly. They tend to transfer this technique to Referendum process, by the simplification of choice between one party's chose or the other's one, as a shortcut to making voting "yes" or "no" without being obliged to understand adequately what the amendments would bring or not.

\section{METHOD}

In the changing environment of political life like in other democratic countries, in Turkiye, media events (pseudo-events), political speeches, polls and political news even political cartoons play a significant role in marketing the politicians' ideas. Although Constitutional Referendum is something above the parties and leaders, the personalization of the controversial ideas occurs during the process of the propaganda war. In this respect, the claim of this study is to discover the dimensions of personalization of politics by researching the process of 2010 referendum of Constitution Amendments in Turkiye. In this respect, a discourse analysis was performed to explore the dialectical relationships between the personalization of politics, the leaders' speeches and the referendum process which has carried out a very radical change to Turkish political life. Then this study includes an applied content analysis on 3 different newspapers, and finally why people did vote for what were focused.

Therefore this study's main claim is, the propaganda process of the referendum had been more focused on leaders instead of the articles to be changed during the propaganda war before the Referendum in 2010, in which one may trace personalization of politics. In this paper mainly those questions were asked: Is there any evidence for political personalization of politics in the political speeches of the political leaders and media news? What were the primary motivations of the voters for saying yes or no to changes? And as a conclusion, What is the relation of those developments with personalization of politics?

Those questions are tested by subjecting three Turkish newspaper's news and two political leaders' speeches to discourse analysis, on the consideration of the constitution referendum, during 
the last month before the referendum. The newspapers are selected according to their ownerships, circulations, being on the left, in the center and the right of the political spectrum. The research is going to be completed by using some survey statistics on the referendum which were performed by some private survey company.

\section{The political environment during the Propaganda Period of the Referen- DUM IN TURKIYE}

The referendum was held for the Constitutional Amendments on September $12^{\text {th }}, 2010$ (exactly 28 years after the military coup, on September $12^{\text {th }}, 1982$, on such a symbolically date). The Turkish Parliament was including four different parties. AKP (AK Party) is the government party which passed the most of the articles to be changed in the Constitution from the Parliament on its own. CHP the main opposition party claimed those amendments had been mostly set to control the judicial system by the government, so, the vote should have been "no." MHP had a similar attitude towards the referendum, and BDP called for boycotting the referendum.

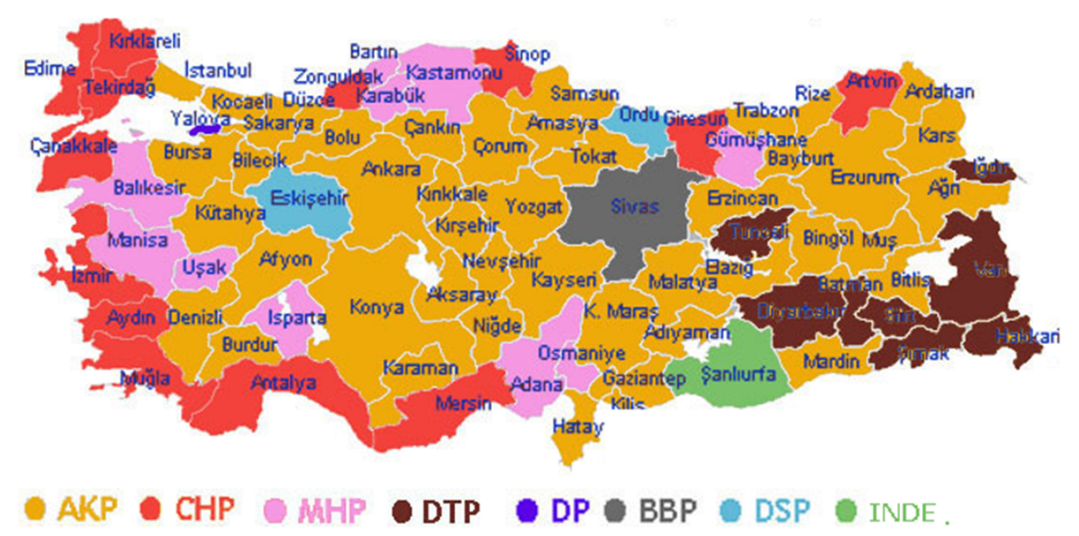

Map 1. The Map of the Results of the Local Elections in 29 textsupersciptth March, 2009, Turkiye.

Source: http://haritalar.web.tr

As it can be observed from the figure map above which party won in where in the Local Elections in 2009. Those parties can be pictured during the referendum process as the following way;

- AKP-AK PARTI (Adalet ve Kalkınma Partisi /Justice and Development Party)

- Founded by Erdoğan and Gül (and B.Arınç) in 2001

- Ideology: Economic Liberalism, Religious Conservatism

- Position: Centre Right (although some AKP deputies belong to Far Right)

- Deputies:332/550 seats (by the General Election in 2007)

- E. Affiliation: European People's Party (observer)

- The Referendum position: YES 
- CHP (Cumhuriyet Halk Partisi /The Republican People's Party, The Main Opposite)

- Founded by Ataturk in 1923

- Position: Centre Left

- E.Affiliation: Party of European Socialists

- Deputies:101/550

- The Referendum position: NO

- MHP (Milliyetçi Hareket Partisi Nationalist Action Party)

— Founded by Türkeş in 1965, refounded in 1992

- Position: Far Right

- E.Affiliation: None

- Deputies:72/550

- The Referendum position: NO

- BPD (Bariş ve Demokrasi Partisi Peace and Democracy Party)

- Founded in 2008, Selahattin Demirtaş and Gülten Kişanak as the co-chairpersons of the party

- Position: Ethnic (Kurdish) Centre Left

- E.Affiliation: Observer in S. International

- Deputies:20/550

- The Referendum position: Boycotting

- The Rest; DSP (Democratic Left Party) 6; TP (Turkiye Party) 1, Independent 20.

In the name of democratic pluralism, there were entirely different groups of deputies as various political parties in the Parliament, during the Referendum process in 2010. But what indivicduals witnessed during the process was more likely to be a propaganda war by and between political leaders than between political parties and opinions about the articles to be changed.

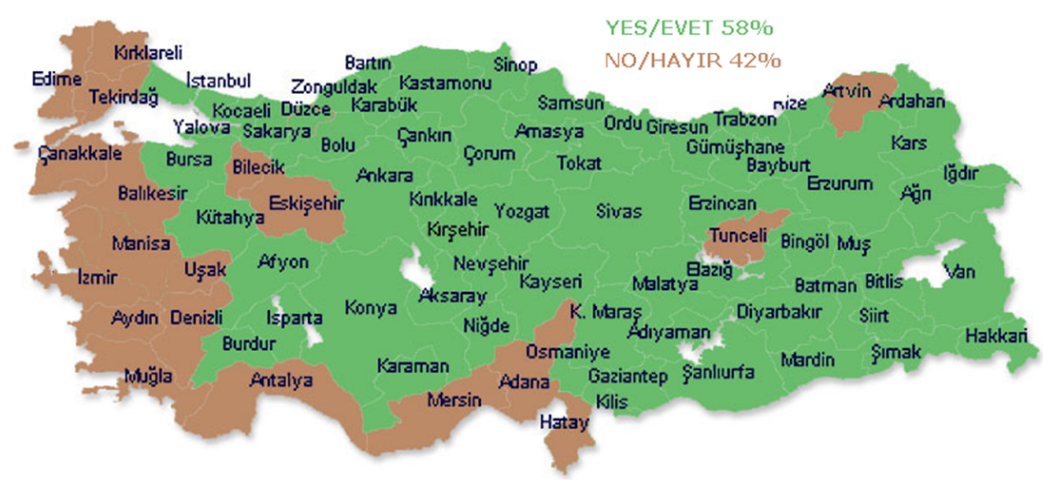

Map 2. The Map of The Results of the Referendum in 2010, September $12^{\text {th }}$ The source: http://haritalar.web.tr

In Turkey, the power party (AKP) and the main opposite party (CHP) could be regarded as "catch-all-party," and the third party MHP's ideology is based on Turkish Nationalism, with taking 
a position of far-right conservatism. When considering about catch-all-party, one should reckon what Mancini and Swanson point out;

Catch-all parties['] (...) main goal is that of raising consensus at the election moment. Their organization structure becomes weaker and weaker, and coexists with a strong capacity by individual politicians for aggregating consensus, mainly at election time, and in the absence of strong ideological ties with the voters. Its constituency is inherently unstable, being dependent on the appeal of a constantly changing cast of individual politicians, a constantly shifting pattern of group alliances, and on the mass media to present appealing politicians in a favourable light. (Mancini \& Swanson, 1996: 10)

This study will focus on that two catch-all parties' leaders' speeches to understand their personalization of politics way. But first of all, clarifying what the personalization of politics is important to understand the rest.

\section{THE PERSONALIZATION OF POLITICS CONCEPT}

Rahat and Sheaffer evaluate political personalization as a process in which the political weight of the individual actor in the political process increases over time, while the centrality of the political group (i.e., political party) declines. (Rahat \& Sheaffer, 2007: 65). Tis paper will not seek to answer "whether there has in fact been an increase in the extent to which the political process has become personalized" (Rahat \& Sheaffer, 2007: 66) in Turkiye. But this study aims to seek to answer whether even the political process of changing social contract has been personalized as well by taking the existence of the personalization of politics in Turkiye as a priori. This study skipped the step of the questioning whether there has been any personalization of political process because in our earlier research about General Election in 2007 in Turkiye provided some evidence about the personalization of politics. For example, Figure 1 and two are summarizing how many times five different newspapers did make news about parties and their leaders in their all pages, in the last six months before the General Election 2007, 


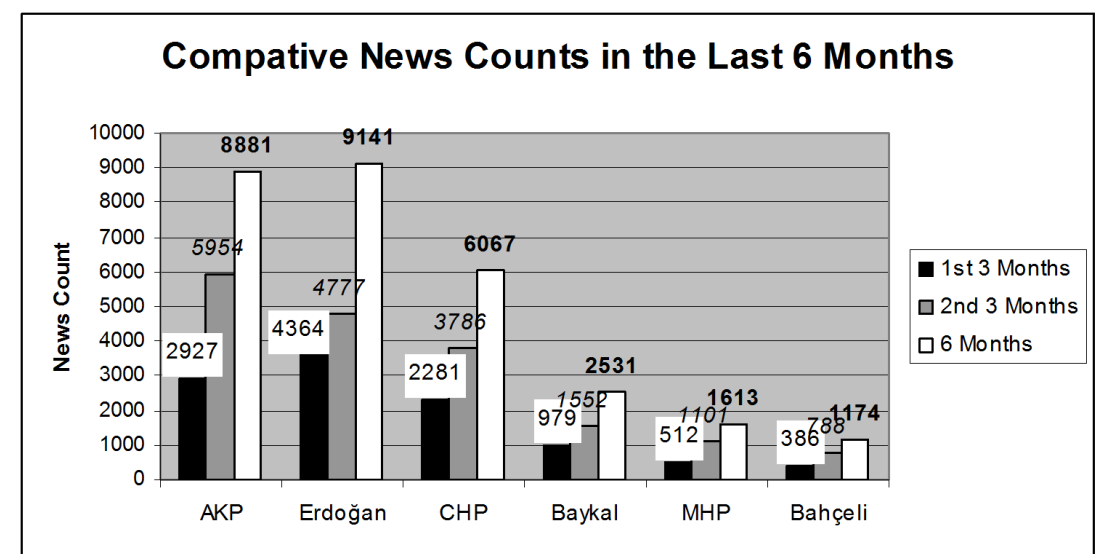

Figure 1. Party News vs. Leader News in the Last 6 Months Before the General Election 2007.

Source: Nigar Degirmenci, Media and Democracy, Doctoral Thesis (in Turkish), Dokuz Eylul University, 2010, (on publishing period).

The Figure 1 reveals that AKP was less represented in the news in the first three months of the period of 6 months before the election, than Erdoğan was. This content analysis result is related to his being the Prime Minister, but also as a result of media personalization of politics. For example, Erdoğan was covered up to nearly four times more than Baykal; eight times more than Bahçeli was.

Another example of personalization of politics from the research in 2007 in Turkiye is presented in the table below. 
Table 1 . News about indirectly or directly related to the leader and emphasis him as "powerful" in 2007

\begin{tabular}{|c|c|c|c|c|c|c|}
\hline & & & & News' Rel & to the $\mathrm{Le}$ & \\
\hline & & Leader & & Indirectly & Directly & Total \\
\hline & & (Powerful) & Period & related & related & \\
\hline & & & $\mathrm{n}$ & 12 & 86 & 98 \\
\hline & & The first 3 months & $\%$ Period & $12 \%$ & $88 \%$ & $100 \%$ \\
\hline & & & $\%$ Total & $5 \%$ & $41 \%$ & $46 \%$ \\
\hline $\bar{z}$ & Frdo ̌̆an & & $\mathrm{n}$ & 13 & 102 & 115 \\
\hline 气 & Eruogan & The last 3 months & $\%$ Period & $13 \%$ & $87 \%$ & $100 \%$ \\
\hline లే & & & $\%$ Total & $6 \%$ & $47 \%$ & $54 \%$ \\
\hline$\equiv$ & & Totol & $\mathrm{n}$ & 25 & 188 & 213 \\
\hline$\overline{2}$ & & Fotal & $\%$ Period & $2 \%$ & $88 \%$ & $100 \%$ \\
\hline 2 & & & $\mathrm{n}$ & & 16 & 16 \\
\hline & Baykal & The last 3 months & $\%$ Total & & $100 \%$ & $100 \%$ \\
\hline & Bahceli & The last 3 months & $\mathrm{n}$ & & 2 & 2 \\
\hline & Bançell & Ine rast 5 montns & $\%$ Total & & $100 \%$ & $100 \%$ \\
\hline
\end{tabular}

Source: Degirmenci, 2010.

The Table 1 is comparing news coverages' of the leaders: there was much more news about Erdoğan, presented him with an image of "powerful". ${ }^{2}$

\section{THE PERSONALIZATION OF POLITICAL CAMPAIGNS}

The more personalized politics creates the more personalized campaign of the ideas. As Mancini and Swanson claims;

The growing tendency to aggregate around individual politicians produces a personalization of politics reflecting the atomization of power, which breaks up into many competing centers that conflict and cooperate with each other and seek a political authority, exercised and personified by a single individual, with which to identify. (Mancini \& Swanson, 1996: 10)

During the referendum propaganda process, each party leader had had many political speeches in many different cities in Turkiye. There were many slogans and posters in use those times. Some of them were like the follow;

- (CHP, Chair Kemal Kılıçdaroğlu) "Whenever Turkey is in trouble, a new Kemal is born!" referring to modern Turkiye's founder Mustafa Kemal Atatürk.

The main difference between Erdoğan's and K1lıçdaroğlu's speeches is about their length. While Erdoğan preferred to speak longer but in less different cities (36 cities), Kılıçdaroğlu had had 2-3 speeches in a day (70 cities), but of course much shorter than Erdoğan did. This study collected 20 statements of both of Erdoğan (as government party leader) and Kılıçdaroğlu (as the main opposite political party leader) in 20 different cities in 7 census-defined Regions of Turkiye.

2. There were also many news about Erdoğan with an image of "victim" (ironically) and "succesful". 
Since the referendum was held on September 12th, the speeches were collected from between August $8^{\text {th }}-$ September 9th, 2010.

\section{Speeches of Erdoğan}

As Mancini and Swanson noted, in thoroughly modernized campaigns, the voter's choice depends increasingly upon the electorate's relationship with the individual candidate. (Mancini \& Swanson, 1996:14) Erdoğan uses this information very efficiently. He builds up a relation with the audiences via using a very particular word: My friend(s) in each of his speeches. In Turkish, there are different words to call elder brother (Ağabey) or elder sister (Abla). Calling as "Kardeşim" or "kardeşlerim" provides a meaning of being called by an elder (big) brother (or sister). By this meaning of the word "kardeşlerim," Erdoğan sets himself as both one of the audiences, and a "big brother", superior to the rest. One can observe the rates of used words in his speeches from the following table below;

Table 2. Descriptive Statistics of the Speeches of Erdoğan

\begin{tabular}{lcccccc} 
In the speeches of Erdoğan; & N & Min. & Max. & Mean & Mean Percentage & Std. Deviation \\
\hline Total Word Counts & 20 & 2584 & 5165 & 3915,95 & 100 & 616,613 \\
"My brother/sister(s)" & 20 & 48 & 82 & 66,55 & 1,690 & 9,534 \\
$\begin{array}{l}\text { Religious Words Counts } \\
\text { "Kilicdaroglu" (CHP Leader) }\end{array}$ & 20 & 14 & 50 & 25,40 & 0,640 & 7,803 \\
$\begin{array}{l}\text { D.Bahceli (MHP Leader) } \\
\text { "The Leader of the party" }\end{array}$ & 20 & 0 & 9 & 1,55 & 0,039 & 1,795 \\
(instead with the name) & 20 & 0 & 9 & 3,20 & 0,081 & 2,395 \\
"Them" (Onlar), refers to & & & & & & \\
all of the opp. & 20 & 2 & $\mathbf{1 5}$ & 6,55 & 0,187 & \\
"Menderes" (The PM & & & & & & 3,471 \\
executed in 61) & 20 & 0 & $\mathbf{4}$ & 1,20 & 0,030 & \\
"Constitution" & 20 & 12 & 41 & 26,05 & 0,660 & 1,005 \\
"From now on"(Artik) & 20 & 6 & 24 & 14,00 & 0,350 & 7,605 \\
No (Hayir) & 20 & 2 & 11 & 5,70 & 0,145 & 2,316 \\
Yes (Evet) & 20 & $\mathbf{1 9}$ & $\mathbf{5 3}$ & 37,00 & 0,940 & 8,467 \\
I/My/I do etc. & 20 & 42 & 110 & 76,40 & 1,950 & 20,682 \\
We/Our/we do etc. & 20 & 97 & 208 & 148,65 & 3,700 & 34,696 \\
Valid N (listwise) & 20 & & & & & \\
\hline
\end{tabular}

As it can be seen from the above, Erdoğan used the following words at least 5 times or more, in every each of his speeches: Yes (Evet); From now on (Artık); My brother(s)/My sister(s) (Kardeşim/Kardeşlerim); Constitution (Anayasa); I/I do etc. (Ben, yapıyorum, etc.); We/we do(Biz, Bizim, yapıyoruz etc.); and Religious words (consist of; Şehit, Ramadan, Turban, Allah [includes Maşallah, İnşallah etc.]). This summary of his speeches personalization of politics is an essential point of the campaign of AKP. First of all, Erdoğan set himself as "big brother" of the audiences. 
According to Campus, the ideal leadership profile should result from the compromise between the right personal characteristics of the candidate and the image that targeted voters seem to like and require (Campus, 2010:222). By using religious content, Erdoğan connects himself to the local culture and henceforth, provides a direct connection between himself- $>$ his personality- $>$ his opinions->his party->his vote with the audiences->their personality->their opinions-> their votes. In this respect, Erdoğan seems good at performing at that creating personalized ideal leader advice about connecting with audiences via personalization.

The second evidence of the personalization of the propaganda speeches is that he highly preferred to use "I" concept sentences, which means, he had explained "what he did, does, will do" during the referendum propaganda process. When considering this referendum was about the Constitutional Amendments, instead of some presidential run or some general election, using personal expressions is supposed to be out of the propaganda content. But again, people live in a personalized political world so the leaders use personal expressions to gain the audiences, so did Erdoğan. Moreover, Erdoğan also used the strategy of calling himself as "we" sometimes too. By doing so, he provides a perception that he and his party are almost inseparable two things. Voting for Erdoğan equals to voting for AKP, and this is supposed to equal for voting for YES.

While Erdoğan used the personalization strategy for himself very often, whenever he needed to mention about the opposite leaders, he used the "anti-personalization" or even "contra-grouping" strategy. There are many speeches of him that he never mentioned about either Kılıçdaroğlu (CHP, the main opposite party leader) or Bahçeli (MHP, the opposite party leader) and there are only a few speeches he mentioned about them (Kılıçdaroğlu max.7 times; Bahçeli max.9 times). He also had used the word "onlar" (them) to call all of the opposite parties; their leaders, and at the end, whoever was NOT going to vote for "YES" (that includes voting for NO; boycotting; and non-voting). This counter-grouping of the opposites forced the audience to think if their political identity were matching with the other the party leaders and their opinions in the same group which identified by Erdoğan during the speeches as well. For example;

In that scenario, some conservative individual may think to vote for $N O$, and also feels close to Bahçeli (MHP), BUT, Erdoğan warns him by saying Bahçeli and Kılıçdaroğlu and BDP (Kurdish party) are all in the same group. When he votes for $N O$, he will support others too.

This strategy was supported by some other expressions of Erdoğan, such as:

"This is not a "vote for a confidence for the Government" (GÜVENOYU). I do not ask you to vote for AKP. My brother, who voted for CHP, MHP, BDP... I want you to vote for the Amendments and say YES!"

Finally, Erdoğan ended each of his speeches like follow;

What was our song? Come on, let's make all of Turkey hear! "We walked down together those roads. We burnt together under the sun. Now whichever song l listen, everything reminds me of you... Everything reminds me of you... Everything reminds me of you" [quoted from a well-known Turkish song] Happy our day, Have a blessed Ramadan. Flags. Flags. [asking from the audiences to hold up the flags of Turkiye] I wish you have a double festival by the September $12^{\text {th }}$ [mentioning about Ramadan Festival and the result of the Referendum] God bless you! 
As Castells claims, political actors devise their strategy by tailoring messages to bring about the most favorable connection between the political leader and the electorate (Castells, 2000: 205) and this repeating concept above is a very good strategy which allows Erdoğan create another connection with the audiences. On the other hand, in the marketing business, there is a "star strategy" which is often used to sell products. In this referendum process, individuals witnessed again, the personalization of Erdoğan strategy supported by Menderes and Özal's credits which can be considered as another "star strategy" but this time it's in politics.

When considering Erdoğan's way to call the opposites, it can be clearly observed that he prefers to "un-personalize" them. He barely calls them with their names but instead, he calls them with "them," or less preferably "The Leader/Chef of CHP/MHP, etc. When considering Kılıçdaroğlu' speeches, rhetorical tactics occur in a very opposite way. He calls Erdoğan with his first name, Recep.

\section{Speeches of Kılıçdaroğlu:"My Name is Kemal, I'll do it!"}

Even though Kiliçdaroğlu uses the personalization strategy by using the nickname for himself as "Ghandi Kemal" (the picture 6); or saying " My Name is Kemal, I'll do it!"; or before his coming up to the stage, having an announcement as "Whenever Turkey is in trouble, a new Kemal is born," (referring to modern Turkiye's founder Mustafa Kemal Atatürk). The analysis of his speeches does not show a robust personalization of the politics for himself, but instead, this study found there was a strong personalization the politics for Erdoğan, by calling him as "Recep Bey (Mr.)". However, by using the credit of Ataturk, he personalized himself but also set himself as "hero" to save the country from "Recep" too.

Table 3. Descriptive Statistics of the Speeches of Kıliçdaroğlu

\begin{tabular}{lcccccc} 
& N & Min. & Max. & Mean & Mean Percentage & Std. Deviation \\
\hline Word Counts & 20 & 1309 & 2859 & 2178,45 & 100 & 357,079 \\
My/I do etc. & 20 & 30 & 84 & 58,35 & 2,670 & 15,932 \\
Our/We do etc. & 20 & 54 & 118 & 78,60 & 3,608 & 19,951 \\
My brother/sister(s) & 20 & 0 & 10 & 3,05 & 0,140 & 2,502 \\
Religious Words Counts & 20 & 0 & 12 & 6,35 & 0,290 & 3,216 \\
Erdogan & 20 & 0 & 3 &, 80 & 0,030 & 1,005 \\
Recep Bey (Mr.Recep & & & & & & \\
(Erdogan)) & 20 & 0 & 52 & 26,90 & 1,23 & 13,183 \\
Menderes (The PM & & & & & & \\
execuited in 60) & 20 & 0 & 12 &, 80 & 0,030 & 2,668 \\
"Constitution" & 20 & 5 & 38 & 16,15 & 0,740 & 8,450 \\
"From now on" (Artik) & 20 & 0 & 6 & 1,90 & 0,087 & 1,774 \\
No (Hayir) & 20 & 0 & 31 & 12,20 & 0,560 & 7,537 \\
Yes (Evet) & 20 & 0 & 15 & 5,45 & 0,250 & 4,199 \\
Valid N (listwise) & 20 & & & & & \\
\hline
\end{tabular}


As it can be seen from the figure above, the personalization of the politics strategy of Erdoğan was supported by Kılıçdaroğlu's speeches. For example, he announced "by voting for YES; you save Recep [Erdoğan]; but by voting for NO, you save the country from Recep" via the party bus amplifier. This Personalization concept of the politics of opposites can be a very dangerous strategy. When the concept is about national issues, like constitutional changes, the amendments are too complicated to be fully understandable, and at this point, individuals need hints and simplifications of the ideas to vote. But making the too simplification of the issues may effect undecided voters in opposite way.

However, Kılıçdaroğlu's speech style was too less personalized than Erdoğan did. He barely used my brother/sister(s) word (kardeşim); he barely used religious words;

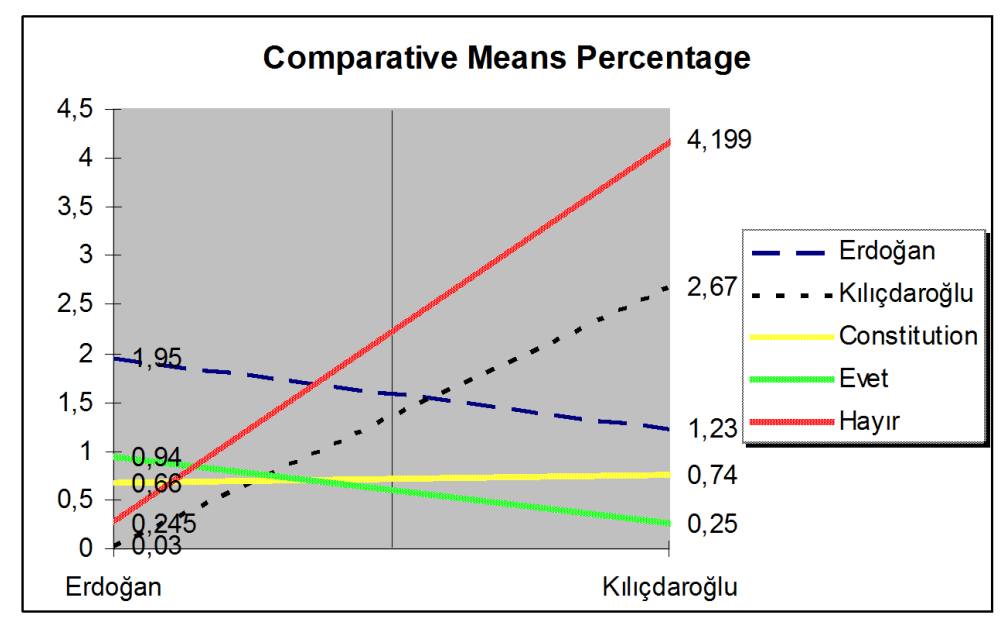

Figure 2. Comparative Percentages of Means of the Word Counts used by Erdoğan and Kılıçdaroğlu

When those two different tables of the speeches were combined, the figure above derived. As it can be seen from the figure, those two words "yes" (Evet) and "no" (Hayır), which are directly related to accepting or rejecting the amendments, are the high or low frequency used due to the leaders' referendum positions. Rates of using the word "Constitution" were low for both of the leaders, however by using the strategy of personalization, mentioning about the individual leaders were far higher than the rest of the concepts. One of the most remarkable points in the figure is the difference between Erdoğan's mentioning about Kılıçdaroğlu, and Kılıçdaroğlu's mentioning about Erdoğan, and also about themselves This summary that Erdoğan prefers personalization strategy for himself but a anti-personalization strategy for the opposite.

\section{THE PERSONALizATION OF NEWS}

In this paper, "personalization of news" were preferred to use, instead of "mediatization of politics" or "mediation" to stay away from theoretical arguments about what mediatization is and is not. Our primary focus here is the news about the politicians and the referendum process. 
According to Wolsfeld, the influence of the news media on a political process is only after a change in political environment;

\begin{abstract}
"a cycle in which changes in the political environment lead to changes in media performance that often lead to further changes in the political environment. It is not a chicken and an egg problem; politics almost always comes first. (...) I shall refer to this principle as the politics-media-politics (PMP) cycle" (Wolfsfeld, 2004:31).
\end{abstract}

If a media exposure becomes only after a change in political environment, this study needs to focus on the political events which were created for media products during the referendum period. However, as Mazzoleni and Schultz point out, the mass media are not mere passive channels for political communicators and political content. Rather, the media are organizations with their aims and rules that do not necessarily coincide with, and indeed often clash with, those of political communicators (Mazzoleni \& Schultz:1999: 249). The media have become as independent from political institutions as any institutions can be from a social systems perspective where total independence is always impossible (Strömbäck, 2008: 240). Thus, no one can expect, or the politicians could not have expected that everything they did would be newsworthy for each newspaper. However, regarding Sim's study's finding which is that the routine personalization of social issues in media discourse also contributes to a significant political effect (Sim, 2006:589), media personalization of politics in the referendum process was traced by subjecting 3 Turkish newspaper's news during the last month before the referendum. Again referring to Mazzoleni and Schultz, the traditional left-right dimension is still the dominant dimension along which parties try to differentiate themselves from each other, even though some socialist and social-democratic parties have moved slightly to the center (Mazzoleni \& Schultz:1999: 254). In that case, one may see the same issue for many newspapers in Turkiye. However, the newspapers were selected according to their ownerships, circulations, being on the left, in the center and to the right of the political spectrum, although some left newspapers and right-wing newspapers slightly to the center, the selected newspaper are more stable due to their position in the political spectrum.

\begin{tabular}{|llr|}
\hline The Left & The Center & The Right \\
$\stackrel{\text { Cumhuriyet }}{\longrightarrow}$ & Hürriyet & Zaman \\
\hline
\end{tabular}

Figure 3. The selected Newspapers and Their Position on the Political Spectrum

Those newspapers examined in this respect; which pseudo-events were newsworthy and relevant for them during the referendum process. Mazzoleni and Schultz claim that mass media present only a highly selective sample of newsworthy events when they satisfy certain rules, commonly understood as the criteria for determining "news value," and often the selection process is determined more strongly by journalistic worldviews and by media production routines (Mazzoleni \& Schultz, 1999:250). In this respect, this study will try to find out which events were newsworthy by which newspapers. 


\section{Pseudo-events concept}

The term was used for the first time in 1961 by Daniel J. By Boorstin, in his book named as "The Image: A Guide to Pseudo-events in America". A "pseudo-event" is an event which has no any other function but taking the public's attention via media in a particular direction. This occasion has been led by irretrievable increasing of human expectations which to be met by the press for the press via re-making press productions (Boorstin, 1987: 3-11). As Pattersons claims, media events must be designed to attract maximum news coverage, and media prefers to focus on a few individuals, the politicians, rather than on the broader interests they represent and the larger political forces that shape their politics" (Patterson 2000: 254). During the referendum propaganda war, there were several political pseudo-events; height fight, villa fight. In those three newspapers, the presentations of the pseudo-events seemed differently. Next, this study will focus on how different they were represented in the newspapers.

\section{The pseudo-events}

"Height"; AKP Deputy Prime Minister B.Arınç stated that "he (Kılıçdaroğlu) is saying something with his such a little height" (Ad Hominem Fallacy ${ }^{3}$ )

"Ancestor"; The Height pseudo-event was followed by this Ancestor-pseudo-event. Erdoğan stated that "Don't look at the height, look at the ancestors". (Ad Hominem Fallacy) In here, he was also underlying Kılıçdaroğlu's being not Sunni.

"Racism"; Kılıçdaroğlu claimed that Erdoğan was a racist. Kılıçdaroğlu asked him to be polite due to his earlier words about "ancestors."

"Betraying claim"; Kılıçdaroğlu accused Turkish PM, and mainly AKP and Erdoğan of betraying country.

"Coup" Kılıçdaroğlu stated that if there was any coup, he would be the one who stands in front of the tank.

"Counteracting to Coup" Erdoğan stated that "if there was any coup, you would be in front of the tank only to salute them."

"Televised debate"; Kılıçcaroğlu invited Erdoğan to a televised debate and "He doesn't have the courage to do it, because he knows his actions are wrong," he said.

"White Shirt" (as metaphor of cerement); Erdoğan stated that "The mentality which threatened to kill and killed Menderes ${ }^{4}$ once upon a time, today says us "We will send you to the Supreme Court". When we on our way for the first time, we put the white shirts on ourselves. We have only one life. No one can take it away but God."

3. Ad Hominem Fallacy: According to the Internet Encyclopedia of Philosophy, If the fallacious reasoner points out irrelevant circumstances that the reasoner is in, the fallacy is a circumstantial ad hominem. The major difficulty with labeling a piece of reasoning as an ad hominem fallacy is deciding whether the personal attack is relevant. the Internet Encyclopedia of Philosophy, www.iep.utm.edu/fallacy/\#Ad\%20Hominem (10.03.2011)

4. Adnan Menderes (Turkish Republic Prime Minister between 1950-1950) was executed in 1961 after a military coup in 1960 . He was found guilty of violating the constitution, of abusing power in the anti-Greek riots, of suppressing the opposition and the students' and sentenced to death penalty by hanging on September 17th, 1961. 
"Cerement": Kılıçdaroğlu replied Erdoğan's "white shirt" statements by "No one can make you wear it. If someone makes it, come to find me, I will be the first who fights against him. But if you steal, I will be the one who will ask you to account"

"Counterfeiter": Kılıçdaroğlu called Erdoğan as "Counterfeiter" on the basis of a prosecutorial investigation, which signed by Erdoğan himself, to be sent to the Parliament. And so, Kılıçdaroğlu stated that "Why do you pretend to be a 'victim' when I mention about that? I will get your mask down!"

"Recep Bey (Mr.Recep)"; Kılıçdaroğlu called Erdoğan with his first name and "Bey" (sir, mister) instead calling him as in a formal way, as Erdoğan, or The Prime Minister etc.

"Official Kemal Efendi", Erdoğan counteracted Kemal Kılıçdaroğlu by implying his being retired official civil servant, and Kılıçdaroğlu counteracted him by saying "I am official Kemal, employee Kemal, retired Kemal. Anyone can call me like this but no one can call me as 'Counterfeiter Kemal'.

"General amnesty proposal by Kılıçdaroğlu"; He promised to rule a new law for "Conditional release for convicted" but he didn't specify his aim at his first related speech. And so, Erdoğan used that in his speeches against to Kılıçdaroğlu.

"Counteracting to Amnesty Proposal": Erdoğan stated that 'I "Do you [Kıllı̧daroğlu] have the authority to bring the general amnesty? I don't even see any such authority in myself. How do you come up with such a proposal? Can you ignore the cries of the mothers and fathers of our [dead soldiers]?

"Villa with a pool"; Ankara Mayor claimed that Kılıçdaroğlu ha d seven properties including a villa with a pool.

"Counteract to the properties claims by Gökçek"; Kıllı̧daroğlu stated that "I do not take him seriously. I have already unmasked [his mishandling]. Now he tries to bring himself back onto the agenda [with such claims]," Kılıçdaroğlu also claimed that Erdoğan owned five villas with pools and with golden faucets. He said, "That's why we say that being in politics will not make us rich,

““'Chief” Erdoğan stated that "They have told me that I couldn't become a Chief (referring his being former Mayor of Istanbul), but today I become a Prime Minister". "Counteract to Chief"; Kılıçdaroğlu stated that "I did not say to you that you could not be a Prime Minister, but you have to be A MAN" (using a Turkish phrase of "I did not tell you that you could not be...[something, anything] ... but I told you that you could not be a MAN.)

Those pseudo-events which created by the political leaders who were presented in most of the newspapers, but different newspapers made news about them differently. This study included here three newspaper views: Zaman Newspaper (right wing, was belonged to Gulen Cemaati, supported Erdoğan in that period), Hurriyet Newspaper (mainstream, belongs to Doğan Media, and the government controls Doğan Holding by their tax debts and public tender bids), and Cumhuriyet Newspaper ( Left wing, founded by Ataturk).

Zaman Newspaper represented Erdoğan with powerful images, and most of the news about Kılıçdaroğlu were in a critical, and even teasing way. Some quotations from Edoğan were not 
with quotes (" ") which look like Zaman Newspaper and Erdoğan think the same. According to Mazzoleni and Schultz, there is growing evidence that some news media organizations try to compete with the political parties and political actors for public consent and legitimation in the same political arena (Mazzoleni \& Schultz, 1999:257). Making news without quotation marks is a kind of strategy for competing with opposite political parties and actors for public consent in the same political arena.

Hürriyet Newspaper is a main-stream newspaper and owned by Aydın Doğan (who has some troubles with the government because of some tax problems. But still the Hurriyet is one of the best-selling newspapers in Turkiye.) The Hurriyet newspaper used both critical and neutral representations of both Kılıçdaroğlu and Erdoğan.

The Cumhuriyet's news about Erdoğan was mostly critical, but still, there was less news about Kılıçdaroğlu. In other words, Erdoğan was represented in Cumhuriyet Newspaper more often than his rivals, even in a critical way, it made him more heard. The agenda was always set by Erdoğan, and best thing his rivals' could do was only replying to him, and some of those "replies" were news-worthy, and most of them were not.

Each media group has the own political position, and due to that position, they have editorial chooses which frame the news about politicians and politics. During the personalization of politics in the period of the referendum, it is even more complicated to make news, because it is hardly separate which is worth to make news about or which is not, which is something personal, private, which is not. And as Castells claims, there is no longer any privacy for political leaders (Castells, 2009:267). In the end, newspapers can not/will not avoid making personal news, but instead, they prefer to make news about them because it is always easy to sell news about not politics but pretending one. However, as Mughan points out, the only media effect worthy of note is that they reinforce political predispositions that already exist (Mughan, 2000:79). In this respect, even though media affects on political personalization is paramount, its effect on voters has always been limited.

\section{The personalization of votes}

The personalization of votes is another angle of the process the last but not the least of course. As Carpara points out, the personalization of politics does not only concern the significant impact of politician's personality characteristics on voter's preferences but also relates to the role of voters' personality on their decision making (Carpara, 2007:153). All the effort about personalization is to gain and to keep votes at the end. To understand the personalization of the votes during the referendum process, this paper made use of some survey results which were done by some private research company. As Angell implies, there has been a parallel process of a growing personalization of politics above ideas and ideology - another trend that reduces public enthusiasm for parties (Angell, 2007:290). This result can be seen in voting reasons. 


\section{Voting reasons in the referendum}

After politicians and media analysis, now the focus is on the voters' decisions. How did they decide to vote? How were they motivated to vote in what direction? To answer those questions, a survey statistics on the referendum which were published by some private survey institution (Metropoll Survey Co.) examined.

As it can be seen from the following figures, the personalization of the referendum ended by in personalization of the voting decision of the majority. It seems that the strategy worked in both positive and negative ways in favors of the politicians.

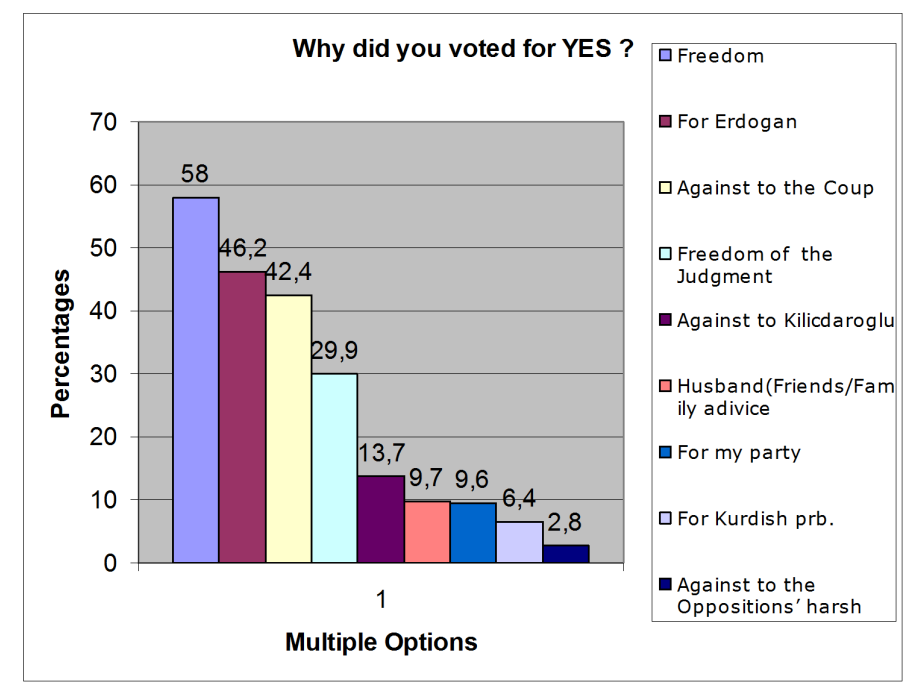

Figure 4. Why did you voted for YES? (Metropol Survey Co.)

Every each one of two YES voters, voted for Erdoğan. If these rates were belonging to some general election, it would be rational, but when consider it was about Constitutional Amendments, this rates proves us a clear evident of the personalization of politics, even if the politics were about the state system, neither elections nor seats in political positions.

This personalization of the referendum process worked against to Kılıçdaroğlu; it was basically in favour of YES voters. 
Referendum process in the era of personalization of politics: a descriptive case study of constitutional referendum in 2010, Turkey

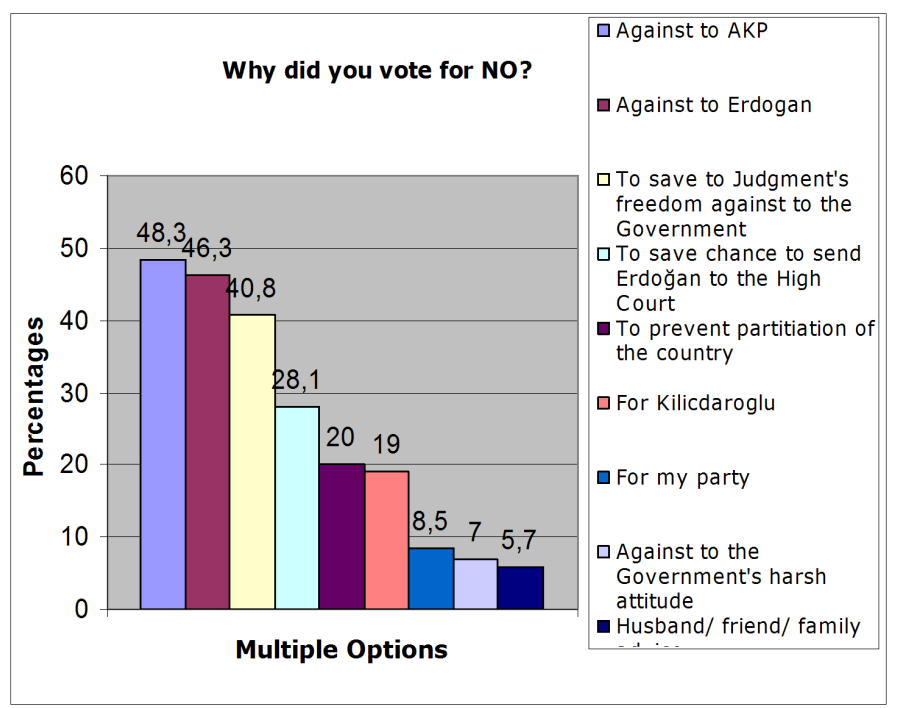

Figure 5. Why did you voted for NO? (Metropol Survey Co.)

According to the survey company, there was a relation between education and vote decision. More educated people voted for "NO" while less educated people voted for "YES." However, we do not have a statistical data about the relation between "why did you vote for YES/NO" and "education."

\section{CONCLUSION}

People live in a mediated environment. People live in the connected networks in which there always some information is coming in and out in $7 / 24$. Personalization of politics on this living political environment is even faster than ever before, more spontaneous, more sophisticated and interactive. Today, politicians communicate each other and with voters via media and social media. Today, personalization of politics by a party leader creates a synergy and media exposure; demands public attention, and thus it requires personalization of other parties' political attitudes too. To be effective, personalized politics strategy needs that the politics to be kept under personalization feed in media. As Kepplinger claims, the changing political coverage, whatever the causes or intentions were, might have contributed to the growing conviction that politicians talk more than they act (Kepplinger, 2002:985 ). These kinds of discussions produced for people as well as media, and thus, as it can be seen from the examined speeches, they are usually rich sources for pseudo-events, and the results of our analyses underline the importance of the individual politicians and their statements' effect on voters' decisions. The following figure depicts that how the personalization has created the snowball effect in time based on media. 


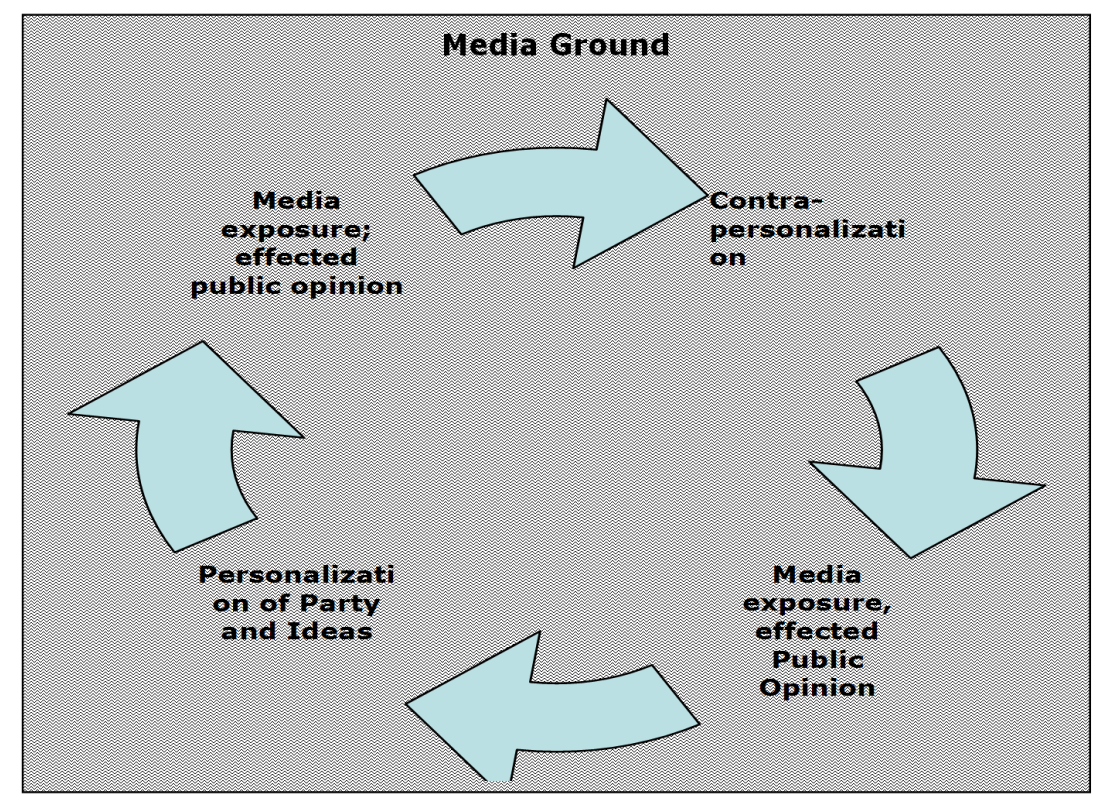

Figure 6. The Spiral of The Personalization of Politics on Media Ground (The inter-active personalization of politics on a mediated ground) (developed by the author)

Our study proves Mazzoleni and Schultz's claim, that is, it is left to the media to decide who will get access to the public; media select and frame events, the media select which actors will receive attention and frame those players' public images (Mazzoleni \& Schultz, 1999:251). This key point also explains the figure above, that personalization of politics could only survive on media ground. If there is no attention of personalization of politics in mass societies the effect of the strategy would be very limited.

On the other hand, the approach of the personalization is likely to be a kind of "double-edged knife." The more personalized politics brings along, the more gained votes but also, the more lost votes as well. This ambivalence is an opportunity for some politicians to manipulate voters while for some others he/he may seem like a threat which may lead lose votes. Using this strategy during a referendum needs to be supported by some other strategy as well. Erdoğan finds out that the strategy would be combining of "contra-grouping" and also "anti-personalization" of the opposites. By using those tactics, he was personalizing of the referendum (for his supporters), he also did pretend to separate the situation from himself (for opposite voters) a the same time. Shortly, everyone could take "the message" which was needed.

Even this study conducted that every political party used the personalization of the politics, this strategy was more often applied by AKP, and specifically Erdoğan for himself than by the rest. Besides, according to the survey results, personalized votes for YES were more than personalized votes for NO. Knowing AKP and in favor of the Amendments won the majority of the votes in Turkiye, this strategy seems successful anyway. 
In this paper, our approach to the strategy of personalization of politics was critical, although some studies evaluate this concept as a way out for democratization of political life. For example, according to Schmitt, voters are in need of functional equivalents which can provide them with plausible criteria for their vote choice without inflating their information- and decision costs. Leadership traits, especially their personal qualities, might be able to fill the gap and gain greater importance for the electoral process (Schmitt, 2000:5).On the other hand, one can ask several questions i.e. "High rates of always voting equal to democratization?", "Can we say that when people vote for leaders, they always vote for the same ideas the leaders think and the voters assume?". Thus, due to our approach, the more personalized politics, especially in a referendum process does not necessarily bring the more democratic process always, but on the contrary, the more personalized politics usually means the more distracted political life in general (particularly in a referendum process).

Of course, there are some other important indicators of the voting decision, such as income, education, sex...etc. The next research would be to study deeper in those aspects too. But the personalization of politics has mainly three angles; politicians; media; public. And thus, analysing it requires a united study of those different aspects of the personalization; politicians, media, and public opinion.

\section{REFERENCES}

Angell, A. (s.d.). The durability of the party system in Chile. In P. Webb \& S. White (eds.), Comparative politics. New York: Oxford University Press Inc.

Boorstin, D. J. (1985). The image: a guide to pseudo-events in America. New York: Atheneum.

Calise, M. C. (2005). Presidentialization, italian style. In T. Poguntke \& P. Webb (eds.), The presidentialization of politics s comparative study of modern democracies (pp. 88-106). Oxford Univ. Press.

Campus, D. (2010). Mediatization and personalization of politics in Italy and France: the cases of Berlusconi and Sarkozy. The International Journal of Press/Politics, 15: 219-235.

Carpara, G. V. (2007). Personalization of modern politics. European Review, 15 (2): 151-164. Academia Europæa, Printed in the United Kingdom.

Castells, M. (2009). Communication power. New York: Oxford University Press Inc.

Degirmenci, N. (2010). Media and democracy. Unpublished Doctoral Thesis, Dokuz Eylul University.

Duverger, M. (1991). Personalizzazione del potere o istituzionalizzazione del potere personale. [Personalization of power or instirationalization of personal power]. In M. Vaudagna (ed.), Partita politico americano e I'Europa [The American political party and Europe] (pp. 259268). Milan: Feltrinelli.

Fairclaugh, N. (2003). Analyzing discourse: textual analysis for social research. London: Routledge. 
Gidengil, E. (2000). Are party leaders becoming more important to vote choice in Canada?. Paper prepared for delivery at the Annual Meeting of the American Political Science Association, Marriott Wardman Park, Washington DC, August 30-September 3.

Kaase, M. (1994). Is there personalization in politics? Candidates and voting behavior in Germany. International Political Science Review, 15 (3): 211-230.

Karvonen, L. (2007). The personalization of politics what does research tell us so far, and what further research is in order?. Paper prepared for the $4^{\text {th }}$ ECPR Conference, Pisa 6-8 September.

Kepplinger, H. (2002). Mediatization of politics: theory and data. Journal of Communication, 52 (4): $972-986$.

Mair, P. (2005). Democracy beyond parties. Center for the Study of Democracy. UC Irvine: Center for the Study of Democracy. Retrieved from: http://escholarship.org/uc/item/3vs886v9, (02.03.2011)

Mancini P. \& Swanson, D. L. (1996). Politics, media, and modern democracy: introduction. In P. Mancini \& D. L. Swanson (eds.), Politics, media, and modern democracy: an international study of innovations in electoral campaigning and their consequences (pp. 1-26). Praeger Publishers.

Mazzoleni, G. (1996). Patterns and effects of recent changes in electoral campaigning in Italy. In P. Mancini \& D. L. Swanson (eds.), Politics, media, and modern democracy: an international study of innovations in electoral campaigning and their consequences (pp. 194-207). Praeger Publishers.

Mazzoleni, G. \& Schulz, W. (1999). "Mediatization"of politics: a challenge for democracy?. Political Communication, 16 (3): 247-261.

Mughan, A. (2000). Media and the presidentialization of parliamentary elections. Palgrave.

Patterson, T. (2000). The United States: news in a free-market society. In R. Gunther \& A. Mugham (eds.), Democracy and the media. Cambridge, UK: Cambridge University Press.

Poguntke, T. \& Webb, P. (2005). The presidentialization of politics in democratic societies: a framework for analysis. In T. Poguntke \& P. Webb (eds.), The presidentialization of politics a comparative study of modern democracies (pp. 1-25). Oxford Univ. Press.

Paloheimo, H. (2005). Finland: let the force be with the leader - but who is the leader?. In T. Poguntke \& $\mathrm{P}$. Webb (eds.), The presidentialization of politics a comparative study of modern democracies (pp. 245-268). Oxford Univ. Press.

Schmitt, H. (2000). Are party leaders becoming more important in german elections? Leader effects on the vote in Germany, 1961-1998. Prepared for delivery at the 2000 Annual Meeting of the American Political Science Association, Marriot Wardman Park, Washington DC, August 31-September 3.

Schulz, W.; Zeh, R. \& Quiring, O. (2005). Voters in a changing media environment a databased retrospective on consequences of media change in Germany. European Journal of Communication, 20 (1): 55-88. 
Sim, S.-F. (2006). Obliterating the political: one-party ideological dominance and the personalization of news in Singapore 21. Journalism Studies, 7 (4): 575-592.

Strömbäck, J. (2008). Four phases of mediatization: an analysis of the mediatization of politics. The International Journal of Press/Politics, 13: 228-246.

Wolfsfeld, G. (2004). Media and path way to peace. Cambridge University Press.

\section{APPENDIX}

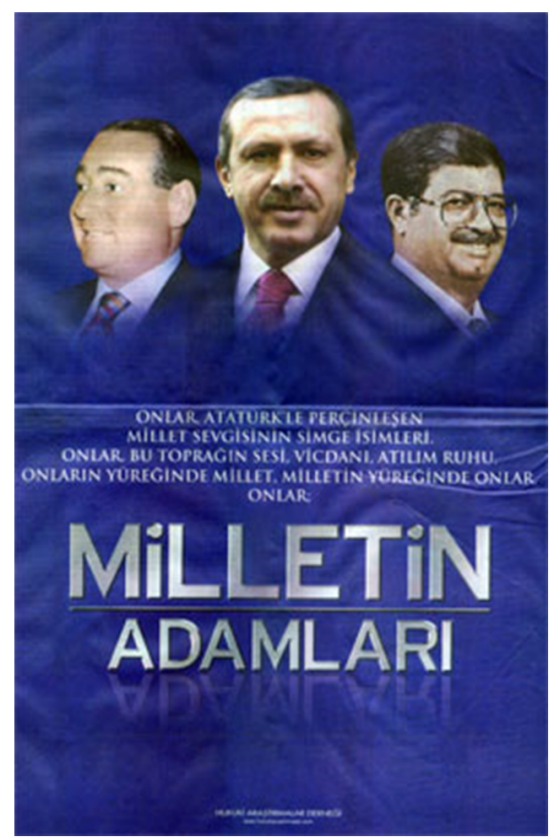

Picture 1. "The Men of the Nation" (a poster from 2007: Menderes, Erdoğan, Özal) 


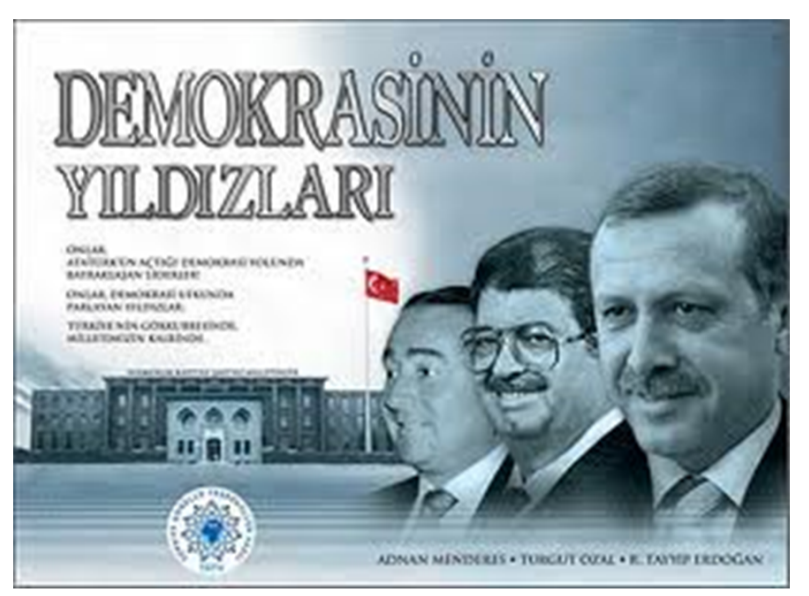

Picture 2. "The Stars of Democracy” (A poster from 2007, Menderes, Özal, Erdoğan -in timeline)

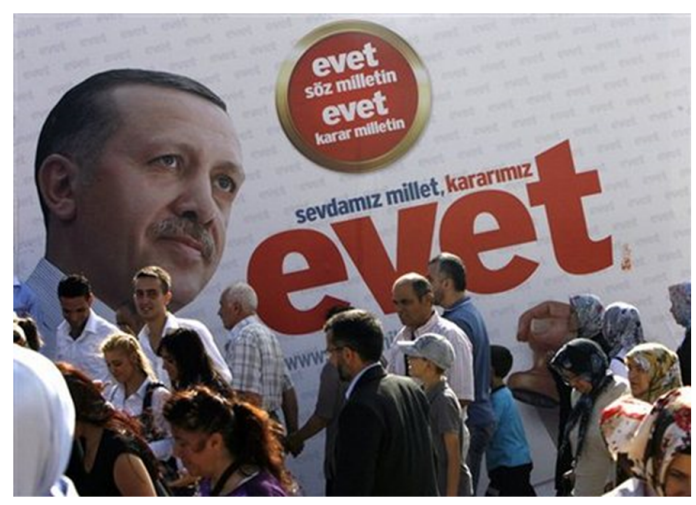

Picture 3. A poster from the Referendum ("Our love is the nation, our decision is yes") 


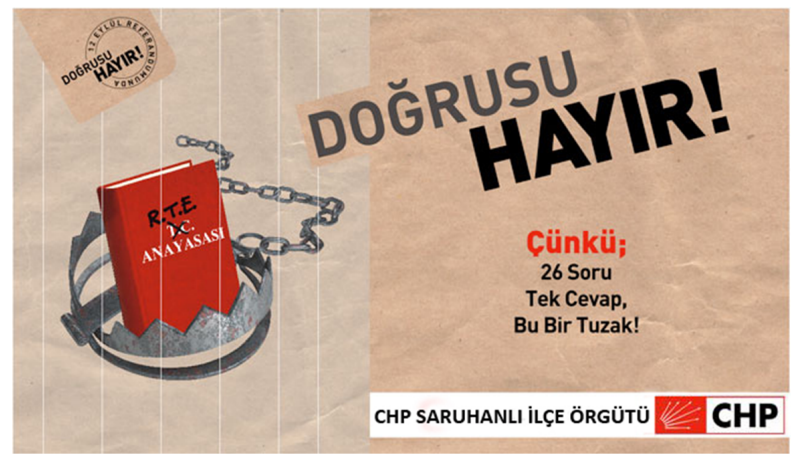

Picture 4. A Poster from the Referendum in 2010, by CHP

"The Correct Answer is NO!. RTE f.C. ANAYASASI" The Constitution of Furkish Republie Recep Tayyip Erdoğan

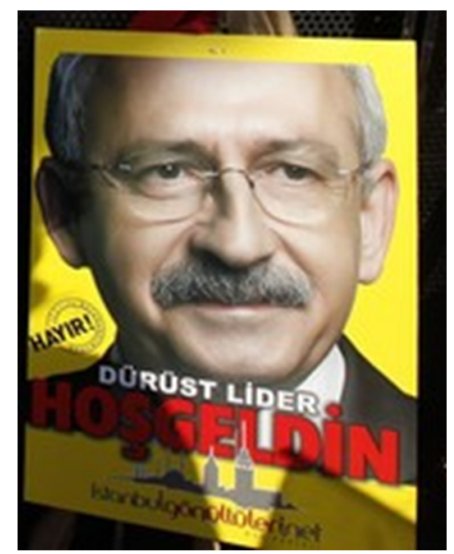

Picture 5. A Poster from the Referendum Meetings, in 2010 "NO! Honest Leader Welcome!" 


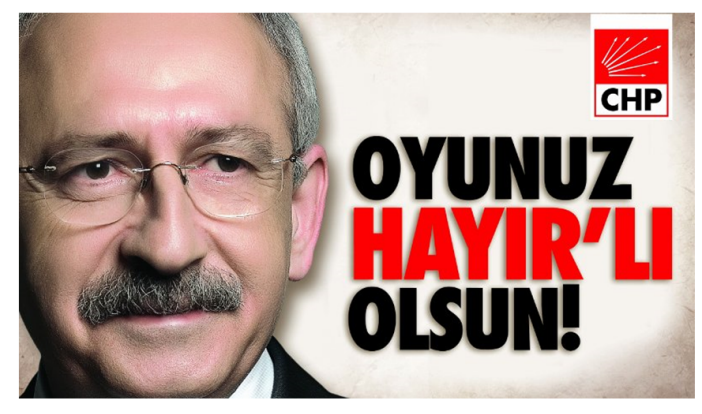

Picture 6.

"Make your vote is with no" () Hayır is in Turkish also means "Good"

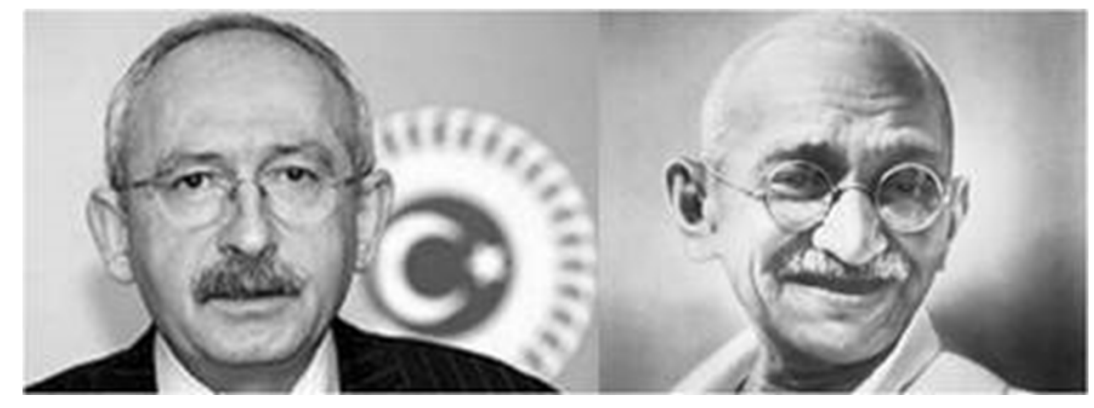

Picture 7. Kemal Kılıçdaroğlu vs. Ghandi 